Rodriguez-Pose and Gill (2003): The definitive, peer-reviewed and edited version of this article is published in Environment and Planning C 2003 vol. 21(3) pp333-51 DOI:10.1068/c0235

\title{
The global trend towards devolution and its implications
}

\author{
Andres Rodriguez-Pose, Nicholas Gill \\ Department of Geography and Environment, London School of Economics, Houghton Street, \\ London WC2A 2AE, England; e-mail: A.Rodriguez-Pose@Ise.ac.uk; N.M.Gill@Ise.ac.uk \\ Received 14 June 2002; in revised form 7 October 2002 \\ Environment and Planning C: Government and Policy 2003, volume 21, pages $333^{\wedge} 351$
}

\begin{abstract}
Globalisation has been accompanied by an equally global tendency towards devolution of authority and resources from nation-states to regions and localities that takes on various forms, depending upon which actors are driving the decentralisation efforts. The existence of a general trend towards devolution also has significant implications for efficiency, equity, and administration. The authors outline first the general drive towards devolution and then proceed to examine which countries are experiencing which forms of decentralisation. A theoretical argument emphasising the role of governmental legitimacy across various tiers of government is used to explain the diversity of devolution initiatives, drawing on examples that include Brazil, Mexico, India, China, the USA, and some European countries. Having supported their model of decentralisation, the authors then examine the implications of the widespread downward transfer of power towards regions. Some of the less widely discussed pitfalls of decentralisation are presented; caution in promoting devolutionary efforts is the prescription of this paper.
\end{abstract}

\section{Introduction}

Research on globalisation has tended to stress the role global processes are playing in undermining the importance of nationally based policymaking, politics, culture, and society. Such trends are underpinned by the proliferation of communication and transportation media, the emergence of dominant forms of international, brand-based capitalism, and the standardisation of various modes of interaction, from the convergence of languages to digitisation (Dicken, 1998). Accordingly, globalisation tends to promote what Agnew (2000, page 101) has called a new international homogeneity across the global order. Such homogeneity implies a certain erosion of the importance of spatiality at the national, and by extension the regional, level as global processes succeed in diluting and internationalising the traditional 'nexus of interactions' associated with local and regional spaces (Gray, 1998; see also Castells, 1996; Massey, 1999; Storper, 1997).

Yet, in spite of this, globalisation is failing to obliterate the importance of the local dimension across the world. In many ways, recent developments point in an opposite direction: towards a greater relevance of place, space, and regions. The growing visibility of the local and regional dimension has many manifestations. Although some argue that the demise of the nation-state is continuing, the rise in regional political activism (Rodr|"guez-Pose, 1998, pages 215f), the increasing importance of regionalism in government (Keating, 1998), and the regionally based competition that mobile capital is inducing (Cheshire and Gordon, 1998) have given rise to a renewed interest in the role of regions. In this paper we will concentrate on one of the most significant recent developments at the global level: the widespread transfer of power downwards towards regions. This process, which in some cases involves the creation of new political entities and bodies at a subnational level and in others an increase in their content and power, is known as devolution (Prud'homme, 1994).

There is now enough evidence to claim that since the outbreak of the process of globalisationöand perhaps as a result of itösubnational units have increased their demands for power. This process has numerous positive aspects but also raises impor- 
tant issues regarding national equity and welfare, public finance, and territorial competition.

The focus of this paper is thus fourfold. First, in section 2, in response to the often simplistic conceptions of devolution, a theoretical model based upon Donahue's (1997, pages $\left.7^{\wedge} 15\right)$ threefold classification of the mechanisms of devolutionölegitimacy and the decentralisation of authority and of resourcesöis introduced. Subsequently, in section 3, we expose the devolutionary process in a selection of countries, including Brazil, China, India, Mexico, the USA, and countries of the European Union. These represent a cross-section of some of the largest areas of the globe and cover the developed and the developing worlds. In section 4, different forms of devolution are compared and examined. In section 5 we critically assess the global implications of the devolutionary trend in light of its evident diversity. In the final section we conclude that a greater awareness of the benefits and drawbacks of devolution is required in order to prevent the escalation of some of the downsides associated with it (section 6).

\section{The theoretical framework}

Devolution is a complex and heterogeneous process. From the high level of decentralisation of certain federal states, such as Germany, and of some Spanish regions, to the more limited power of regions in France or, until recently, Mexico, decentralisation processes across the world have taken on a variety of forms. Consequently, conceptualisation of devolution is far from simple. Looking for a minimum common denominator, Donahue $\left(1997\right.$, pages $\left.7^{\wedge} 15\right)$ characterises the process as being made up of three separate factors: legitimacy, the decentralisation of resources, and the decentralisation of authority. Any form of devolution implies some degree of subnational legitimacy and some form of decentralisation of authority and resources; consequently, any analysis of devolution should take these three factors into consideration.

There is, however, a need for caution in examining evidence, because a simple list-based approach may overlook the interaction between the elements. The complexity of the devolution process derives from the interest conflicts of the actors involved and the differences in legitimacy that they share. Most importantly, the interests of subnational and national governments tend to be at odds across the component factors of devolution. Although national governments would prefer, ceteris paribus, to devolve responsibilities (authority) to their regional or state governments with as few accompanying resources as possible, the subnational governments would prefer the opposite case. The balance between these extremes will depend upon the relative strength, or, in political terms, legitimacy, of the two tiers of government.(2) In figure 1 we illustrate this approach.

(1) Prud'homme's (1994) classification of decentralisation into spatial, market, and administrative decentralisation provides a useful conceptualisation. For the work in this paperöconcerned with administrative decentralisationöthe redistribution of decisionmaking to lower government tiers (deconcentration) and the closer involvement of semiautonomous organisations (delegation) hold less importance than the third type of administrative decentralisation that Prud'homme outlinesö that of power transfer to lower government tiers (devolution). As a consequence, throughout this text decentralisation will be taken to refer to devolution.

(2) Donahue conceptualises legitimacy as incorporating 'popular support' and 'citizen cooperation'. He states that, "ultimately the most important asset that government can command ... is not legal authority, or fiscal resources, or even talented personnel, but legitimacy" (Donahue, 1997, page 12).

If we begin at the bottom of the diagram, we can see that the legitimacy of subnational and national governments is determined for the most part by processes of history and political support. Regarding historical processes, culture, language, religion, and ethnicity have traditionally been the factors behind a strong regional identity and determine the legitimacy of subnational claims (see Litvack et al, 1998, page 1). Economic development has also recently been added to the list (Allmendinger and Tewdwr-Jones, 2000; Keating, 1998). Regarding political support, the inclusion of legitimacy into the analysis brings into play a wealth of political factors that shape the power and room for manoeuvre of governmental tiers. An important caveat here, however, is that a 
reasonably effective political and democratic system must be in place to facilitate the influence of the electorate. This being the case, and all other things being equal, poor political support for the regional cause would translate into a relatively weak regional legitimacy and tend to promote a devolutionary process in which the central government holds the upper hand, favouring progressive decentralisation of responsibilities and often forcing regional and local governments "to undertake increasing expenditure responsibilities on a static, and often narrowing, financial base" (Bennett, 1997, page 330). In contrast, a strong regional legitimacy, underpinned by high political support for the regional lobby, would favour a more rapid decentralisation of resources, as there would be strong demand for such transfers to subnational tiers of government. In general, the combination of historical and political factors in democratic countries shapes the legitimacy of governmental tiers, the relative strength

\section{FIGURE ONE HERE}

Figure 1. The complexity of devolution. Note: double-lined boxes and arrows indicate initial factors and processes, respectively; single-lined boxes and arrows indicate subsequent factors and processes, respectively.

of their respective lobbies, and hence the forms that devolution initiatives are likely to assume. In nondemocratic systems, however, the influence of the electorate is compromised and other factors, which are less transparent, take on more importance in the determination of the legitimacy of government tiers.

As depicted in figure 1 by the single-lined boxes and flows, the importance of legitimacy and popular support does not end at the initial stage. There is also an endogenous role (if we assume again an operative political and democratic system). Following initial moves towards devolution, in terms of decentralisation of resources or authority, the popular perception of devolution will subsequently impact upon the legitimacy of the two government tiers. It is difficult to predict what direction this impact will assumeöit is just as feasible to envisage a popular approval or disapproval of decentralisation originating from the centre, for example. Approval would mean a strengthening of central legitimacy and disapproval would lead to a relative reduction, which, in turn, could be translated into greater or lesser transfers of authority and/or resources from the centre to the regions. Although the political reaction to devolution is case-specific it nevertheless remains an important driver in the evolution of legitimacy between the two tiers, wherever a reasonable democracy has taken root.

In general, an understanding of the interaction between legitimacy and the transfer of resources and authority is imperative to the examination of devolutionary trends (Donahue, 1997). A case that depicts strong decentralisation of resources displays no more evidence for devolution than one showing strong decentralisation of responsibilities. It merely indicates a different type of devolution, driven by different levels of government, and deriving, ultimately, from a different allocation of legitimacy across governmental tiers. Moreover, following from this, we should not necessarily expect cases to depict high levels of both resource and responsibility devolution, because forces often operate to promote their mutual exclusivity. It is with this conceptualisation in mind that we approach recent devolutionary efforts.

\section{The global trend towards devolution}

Before the onset of globalisation the world was dominated by strong national governments, and regional governments tended to be either weak or nonexistent. Hence in Europe, with the exceptions of Austria, Germany, Switzerland, and Yugoslavia, as well as in Africa and Asia, central governments dominated throughout the postwar era. Latin American countries also had centralised states. Although some countries officially maintained federalist or regionalist constitutions, such as Brazil, Mexico, and Venezuela, they tended to be federalist on paper, with regions and states representing little more than administrative units. In the former Soviet Union (USSR) the situation was similar to that of Latin America. The USSR consisted of a union of sovereign 
states on paper, but, in reality, was heavily centralised and controlled from Moscow. Outside this framework, only the above-mentioned European countries, Australia, Canada, India, and the USA had systems in which the regional tier of government played any significant role, and even in some of these cases the role of regional governments had been waning. This was, for example, the case of the USA, where the power of the states had been declining with respect to those of the federal government since at least the reforms introduced by Franklin Roosevelt during the Great Depression (Donahue, 1997); it was also the case in India, where the centrally based mechanism of planned economic development undermined the power of the regions, as the central government dictated financial and economic goals to the states (Sury, 1998). At the beginning of the 21st century this panorama has radically changed. A devolutionary trend has swept the world. In some cases, subnational turbulence has led to the demise of former countries and to the emergence of new states. The fifteen constituent republics of the former Soviet Union have become independent states; Czechoslovakia peacefully split into the Czech Republic and Slovakia; four new states have emerged out of war-torn Yugoslavia, and Kosovo and Montenegro may follow suit. This phenomenon is not, however, exclusive to former Central and Eastern European socialist countries. Eritrea achieved independence after a long guerrilla war, and East Timor has recently become an independent state after twenty-five years of Indonesian occupation.

The emergence of new independent states is an extreme form of a more general, global trend in the transference of power, authority, and resources to subnational levels of government. Few spaces around the world have remained untouched by this trend. Eight out of the fifteen members of the current European Unionöaccounting for 87\% of its population (Rodr|"guez-Pose, 2002, page 174)öhave seen some level of decentralisation. In addition to the already federalised Austria and Germany, Belgium became a federal state in the early 1990s, and Italy is in the process of federalisation. Spain, despite not being a federal state, is arguably the most decentralised state in Western Europe. France has taken limited steps towards regionalisationöwith ongoing debates over the granting of regional autonomy to Corsica. The United Kingdom and Portugal have also transferred a considerable amount of power to some of their regions. Similarly, Poland has recently followed the path towards regional devolution.

Outside Europe, devolution has also been widespread, especially in large and heterogeneous states. In some cases, regional autonomy has been granted ex nihilo. This is the case for Indonesia, which passed autonomy laws aimed at undoing decades of extremely centralised government and at appeasing separatist tendencies in 1999 (Aspinall and Berger, 2001). In China, although political devolution has not formally occurred and the Chinese Communist party still keeps a tight grip on political developments, there has been widespread fiscal decentralisation that has provided regional and local governments with considerable powers and that has encouraged policy innovation at the regional level (Ma, 1996, page 5).

In other cases, preexisting levels of regional autonomy have been enhanced. The most striking cases have been those of Latin American countries. In Mexico the collapse of the economic system in 1982 and the political uncertainty that followed led to extensive changes in territorial politics. Although Mexico's constitution has officially been one of federalism since at least the revolution of 1910 (Rodr|"guez, 1998 , pages $236^{\wedge} 238$ ), extreme presidentialism and the dominance of the executive branch of government ensured seventy subsequent years of centralism and an enduring centralist culture (Rodr|"guez, 1998, pages $235^{\wedge}$ 236). But, asWard and Rodr|"guez (1999, page 28) assert, the last two decades have seen a dramatic improvement in the political systems of representation, accountability, flexibility, and democracy and have led to a profound reform of territorial politics in support of greater federalism.

In Brazil, the power of the states has been reinforced since the passing of the 1988 Constitution. The 'regional interest' lobby was extremely influential during the drafting process and was well placed to capitalise on the anti-central-government sentiment 
that had been developing during military rule (Coutinho, 1996, page 7). The regions were able to secure residual powers of legislation and maintain a lack of any clear constitutional demarcation of responsibilities between the state, the centre, and the local governments (Dillinger and Webb, 1999, pages $9^{\wedge} 11$ ). This has subsequently afforded them a hitherto unprecedented level of discretion over their own financing, administration, and responsibilities.

Among states that had considerable regional autonomy before the onset of globalisation, the trend has also been towards even greater decentralisation. In India, the overconcentration of power in the hands of a few national elites until the early 1980s brought about a reaction that started to redress the balance from the centre to the regions (Sharma, 1999). In the USA, the trend towards centralisation, which some trace back to the American Civil War or to the Great Depression, started to be reverted during Nixon's presidency in the early 1970s (Donahue, 1997), but it was really under Reagan's New Federalism in the 1980 s when states began to recover greater freedom of action.

The global trend towards devolution is based on subnational legitimacy and implies greater transfers of authority and resources from the centre to the states or regions. In most cases, and as in previous waves of decentralisation, regional legitimacy has historic, linguistic, religious, and/or cultural roots. Regions and states with their own ethnic, historical, cultural, or linguistic identity have paved the way for decentralisation. That has been the case for Catalonia and the Basque Country in Spain, for Scotland in the United Kingdom, for Brittany and Corsica in France, and even for Chiapas in Mexico and for Tibet and Xinjiang in China, which have 'brandished' ethnic, cultural, or historical arguments as the source of their demands for greater autonomy. Economic arguments are also increasingly becoming a source of subnational legitimacy (Keating, 1998). Uneven regional economic development, alongside the achievement of greater economic efficiency through decentralisation, are coming to the fore and gradually starting to occupy the bulk of the regionalist discourse in favour of decentralisation. The Northern Italian Leagues were the first to base their devolutionary claims heavily on economic demands after their failure to gain visibility by highlighting traditional ethnic or linguistic issues (Diamanti, 1993). Nationalist and regionalist parties in Spain have increasingly resorted to similar arguments, as indeed have the Zapatistas in Chiapas.

Additional factors also contribute to boost the legitimacy of calls for decentralisation. In some circumstances, decentralisation goes hand in hand with democracy. This is the case for Brazil and most of Latin America, where the advent of democracy and decentralisation are intrinsically related (Shah, 1991; Souza, 1997). Spain represents a similar case: forty years of dictatorship generated greater legitimacy for the devolutionary cause and contributed to the profound territorial transformation of the Spanish state after the return to democracy (Pe"rez D|"az, 1990). In other circumstances, decentralisation tends to accompany changes in the economic regimeöespecially moves towards the marketisation of national economies. This trend has been followed in India, China (Ping, 2000, page 180; Da-dao and Sit, 2001, page 29), and, to a lesser extent, in Mexico and Brazil, since the opening of these countries to trade. The process of devolution operates through transfers of authority and resources. Subnational governments across the globe currently enjoy greater authority and powers than they did a few decades ago. The trend is widespread. The powers of Italian regions have progressively increased since the late 1970s, and today they exercise considerable control in the fields of agriculture, tourism, regional planning, environment, and economic development (Rodr|"guez-Pose, 2002). All Spanish regions now have competence for health and education, and some have also secured powers over policy areas such as policing, taxation, and fiscal affairs, which have traditionally been the prerogative of the nation-state (Castells, 2001). The Scottish Parliament enjoys tax-raising and law-making powers, and the Northern Ireland Assembly, the National Assembly for Wales, and the Greater London Authority have taken over varying levels of central government activities (Tomaney, 2000; Tomaney 
and Ward, 2000).

Outside Europe, a similar transfer has occurred. The USA has, for example, witnessed devolutionary efforts centred around two key areas: welfare and medical insurance (Schram and Soss, 1998). In Mexico, the transfer of power from the centre to the states includes: the increased ability of states to raise revenue; greater control for the states over development funds; a strengthened administrative capacity for the municipalities; and a clarification of the divisions of responsibility between different tiers of government (Rodr|"guez, 1998, pages $251^{\wedge}$ ^252). In India, state responsibilities embrace public order, police, prisons, irrigation, agriculture and related activities, land, public health, industries other than those centrally assigned, and trade and commerce. In addition, states share with the central government authority over economic and social planning, education, labour, and forestry (Bagchi et al, 1992; RBI, 2000). Chinese reforms since 1980 have been aimed at transferring to provinces greater responsibility for budgets (Ma, 1996, page 5). The Brazilian Constitution of 1988 grants, as mentioned above, state governors all those powers not otherwise prohibited by the Constitution (Dillinger and Webb, 1999).

Last, decentralisation has also implied a substantial transfer of resources from the centre to the regions. In figure 2 we illustrate the growth in subnational government expenditure as a proportion of total government expenditure in our case-study countries between 1982 and 1999. Readers should be aware of the limitations of these data from the International Monetary Fund as they do not convey the degree of local spending autonomy of subnational governments, do not distinguish between sources of tax and nontax revenues, intergovernmental grants, and other grants, and do not disclose what proportion of intergovernmental transfers are conditional or discretionary (Ebel and Yilmaz, 2002, pages $6^{\wedge} 7$ ). However, given the lack of alternative, more detailed, and credible data sources, as well as the strength of the general trends identified here, these data must suffice for our purposes. Two points are apparent. First, in the group of countries as a whole, there is an average increase of around $15 \%$ in the proportion of subnational government expenditures. Second, as the framework in figure 1 implies, not all countries are party to this trend. Some countries (that is, Brazil, China, and Spain) have witnessed a considerable decentralisation of resources, which, in the case of Brazil and China, has not been accompanied by similar

\section{FIGURE TWO HERE}

Figure 2. Subnational expenditure as a percentage of total Government expenditure. Note: in the case of Brazil, Mexico, Spain, and the USA, figures include local government expenditure as well as state or provincial expenditure (source: IMF, various years).

levels of decentralisation of authority. In other cases, such as India, the decentralisation of authority has not been matched by a similar decentralisation of resources, as the share of central government expenditure increased slightly at the expense of that of regional government during the period of analysis.

\section{Differing forms of devolution}

Having established the existence of a widespread trend towards devolution in this section we address its diversity, with reference to the theoretical discussion in section 2 . Recall we examined the interrelationship between the legitimacy of governmental tiers and the form of devolution we can expect to find in a given country. In general, all other things being equal, where subnational governments have enjoyed relatively strong legitimacy [as in the case of Spain (Rodr|"guez-Pose, 1996)], devolution biased towards the decentralisation of resources can be expected; in contrast, where the central government has dominated [as in the case of the English regions (Jones, 2001; Morgan, 2002, page 802)], greater decentralisation of responsibility may well ensue. In this section we present support for this contention by examining the cases of China, India, Brazil, Mexico, and the USA. 
China's efforts towards decentralisation began in conjunction with its marketisation initiatives in the late 1970s. The recognition that marketisation warranted a shift in government outlook, from a commanding role towards facilitating functions, brought about a series of fiscal reforms that saw the centre's influence over public resources reduced markedly across the 1980s (Ping, 2000, pages $180^{\wedge} 181$ ). By 1993 the provinces held control over revenue collection, with the centre's share in total revenue falling from 35.8\% in 1983, to 22\% in 1993 (Yi and Chusheng, 2001, page 86). In terms of figure 1, therefore, provincial legitimacy had soared to unprecedented levels, largely because of the enthusiastic nature of devolutionary initiatives. Furthermore, the importance of the provinces was compounded by the introduction of negotiation-based fiscal contracting between the provinces and the centre at the end of the 1980s (Lee, 2000, pages $\left.1009^{\wedge} 1015\right)$, which allowed certain states, especially the richer ones, to exploit their bargaining positions to a far greater extent than under the previous formulabased revenue-sharing contracts. The impacts of this rise in the power of the provinces in relation to the centre soon became evident. Alongside the stated increase in subnational revenue claims, the provinces were able to extract far more aid from the centre than the centre itself could afford, contributing to the national deficit spiralling from parity to 600 billion yuan between 1985 and 1995 (Yi and Chusheng, 2001, page 90). Inevitably, this effect was skewed towards the richer provinces, whose bargaining positions were stronger, and $\mathrm{Ma}\left(1996\right.$, pages $\left.22^{\wedge} 23\right)$ documents a dramatic decline in the progressivity of transfers from the centre to the regions between 1983 and 1991 . Alongside this, as figure 2 illustrates, the central government's share in public expenditure fell steadily, from around 53\% in 1982, to under 30\% in 1998, hindering macroeconomic control and prompting emergency widespread fiscal reforms in 1994 (Bahl, 1999, pages $\left.105^{\wedge} 129\right)$. Although these fiscal reforms succeeded in increasing the centre's involvement in revenue raising, Lee $\left(2000\right.$, pages $\left.1009^{\wedge} 1015\right)$ documents the influence the provinces had in preserving their expenditure levels, undermining the centre's equilibrating efforts. But, although resources have been decentralised, many subnational governmental responsibilities, in accordance with the marketisation of China, have been discontinued, including large areas of responsibility over state-run enterprises. Overall, China's provinces can be seen to have increased their legitimacy markedly over the past twentyfive years, leading, as figure 1 would predict, to a surge in regional financing in excess of any accompanying devolution of responsibility.

The 1988 Brazilian constitution was written in an environment of pronounced hostility towards central government control (Hagopian, 1996, pages $259^{\wedge} 262$ and $268 \wedge$ 269). Constitutional provisions to curb national party dominance resulted in a lack of consistent central politics, a persistent feature of the Brazilian system since the return to democracy. In 1990 the twenty-seven states were represented at the central level by eleven different parties (Kraemer, 1997, page 35), and in such a climate it comes as no surprise that state legitimacy and power have outweighed that of the centre. As Dillinger and Webb point out, "even when the President seems to have strong political support on a roll call vote, that support is the result of extensive prior negotiations and concessions to regional interests" (1999, page 11). The power of the states has been translated into unruly fiscal behaviour. States overspent massively during the late 1980s and 1990s, to the extent of printing their own money, borrowing from their own banks, and running up huge state-level debts (Dillinger and Webb, 1999, pages $\left.23^{\wedge} 25\right)$. Subsequently, the central government has serviced these debts and has faced little choice but to offer financial assistance to struggling states (Montero, 2000, page 67).

More recently, from the mid-1990s onwards, large debtor states have repeatedly threatened the central government with default (Dillinger and Webb, 1999, pages $25^{\wedge} 26$ ) and in January 1999 seven state governments declared themselves bankrupt, contributing with their action to an economic crisis. Hence, state legitimacy can be viewed as so strong in Brazil that not only have devolution initiatives been biased towards resource devolution but also resource devolution has been paid for by the centre itself. Moreover, when individual fiscal packages with the states were eventually negotiated, beginning with Sa $\neg 0$ Paulo in 1997, the lack of extra debt-servicing responsibilities for large debtor 
states confirmed that states had secured such a degree of legitimacy as to be able to promote resource-biased decentralisation yet avoid responsibility (Dillinger and Webb, 1999, pages $25^{\wedge} 26$ ). Brazil therefore epitomises both the rapid decentralisation of resources and the gradual decentralisation of responsibility that we would expect, from figure 1, to proceed from high subnational governmental legitimacy.

India presents a contrasting case. Here, the continued legislative and administrative dominance of the central government has engendered a very different decentralisation trajectory. Whereas the Chinese and Brazilian central governments yielded readily to the provinces and states, the Indian central government maintained its influence and managed devolutionary initiatives largely to its own advantage. Historically, although India is a highly decentralised country, the influence of the central government has been consistently high. Following British rule, which emphasised the centre as a means of coordination of export and political control, the regimented system of five-year economic plans has guaranteed the preservation of central legitimacy. So when, during the 1980s, fiscal imbalance began seriously to affect the national budget, with the internal debt of the central government rising from 15.9\% of GDP in 1980/81, to $33.6 \%$ in 1993/94 (Buiter and Patel, 1997, page 36), the temptation to exploit this legitimacy advantage and to decentralise responsibilities began to manifest itself. The Indian federal system is based upon three lists of responsibilitiesöaccruing to the centre, the centre and the states, and the states alone. The centre's progressive redefining of the contents of the state and joint lists has allowed the central government subtly to raise the responsibilities of Indian states over the past twenty years (see Bagchi et al, 1992; RBI, 2000). Simultaneously, aid to the states as a proportion of state expenditure has actually fallen, from $54.3 \%$ in $1990 / 91$ to $50.6 \%$ in 1998/99 (ICSO, 1999). To find that central expenditure as a proportion of total public expenditure has risen slightly over the period (as figure 2 illustrates) therefore comes as no surprise. As discussed in section 2, this fact should not be taken as evidence of centralisation but, as the preceding discussion confirms, a symptom of the form of devolution India has experienced, underpinned by central legitimacy and consequently dominated by the central government's agenda.

Mexico and the USA represent intermediate cases. Political currents in Mexico have also had a decentralising effect. Through the presidencies of de la Madrid $\left(1982^{\wedge} 88\right)$, Salinas $\left(1988^{\wedge} 94\right)$, and Zedillo $\left(1994^{\wedge} 2000\right)$ the historical dominance of the centre has been progressively undermined. This is owed in large part to political developments that served to make the centre more accountable and at the same time providing regional politics and politicians with ever-increasing legitimacy. These developments have taken various forms. The first set of changes took place in national politics. The incorporation in 1977 of 100 (out of 400) seats based on proportional representation, as opposed to the original, and remaining, first-past-the-post allocated seats, gave opposition parties some institutional voice at the central level (Ward and Rodr|"guez, 1999, pages $23^{\wedge} 27$ ). In 1986 this representation was increased again as seats allocated on the basis of proportional representation swelled to account for 200 of the 500 congressional seats.

Regional politics provided opposition politicians with a second forum. The central government, suffering from a legitimacy deficit in the mid-1980s (Rodr|"guez, 1998, page 241), took the first steps towards greater decentralisation, but, with time, the process led to a rise in state legitimacy. As one would predict from figure 1, devolution initiatives have graduated from emphasising the decentralisation of responsibilities to the states initially, towards a much more well-funded programme as states have risen in political terms and the fallibility of the centre has developed. Hence, under de la Madrid, although devolution initiatives emphasised the 'autonomy' of regions and included many initiatives designed to give the states and municipalities of Mexico 'greater freedom' over their own governance, these policies could be dismissed as either lip service or thinly veiled excuses to dump expenditure responsibilities on the states (Ward and Rodr|"guez, 1999, pages $51^{\wedge}$ (53). During Salinas's presidency further responsibilities were devolved to the states and localities, including comprehensive welfare duties. During this period the election of opposition governors began to shift the legitimacy 
balance in favour of the states. Finally, Zedillo's ascendancy to the presidency brought with it the renunciation of presidential metaconstitutional powers and the initiation of a cross-party forum on intergovernmental relations that has defined drives towards a new federalism in the country since 1996. The level of transparency and cogovernance these initiatives have achieved have guaranteed the states at least a reasonable accompaniment of resources with each devolutionary effort (Ward and Rodr|"guez, 1999). In general, then, the 1980s and 1990s have witnessed an increase in devolution of resources alongside devolution of responsibility as a result of political changes that have acted to equalise the relative legitimacy of governmental tiers, in line with the mechanisms illustrated in figure 1.

The case of the USA, in spite of significant political and economic differences, bears some similarities to the case of Mexico. As in Mexico, it was the centre, under the presidencies of Nixon and Reagan, that initiated drives towards devolution (Donahue, 1997). Indeed, Nixon coined the phrase 'New Federalism' in his bid to involve the states more closely in national governance. Popular disillusionment with the centre during the 1970s and 1980s, following the Vietnam War, the oil crises, and a shift in ideological principles away from macroeconomic management, served as a convenient political platform from which to launch various responsibility-shifting policies. The 1990s, during Clinton's presidency, saw a continuation of this trend, with the introduction of block grants for welfare shifting much of the risk and decisionmaking capacity for social security to the states, but including only nominal, and potentially short-lived, increases in funding (Powers, 1999). Central legitimacy, therefore, had so far served to emphasise responsibility-biased devolution in the USA.

As with Mexico, however, there have been forces operating to dilute this dominance, which have gained greater momentum over the past ten years. Whereas Mexico experienced an exogenous strengthening state-level legitimacy, driven by the political revolution, America's states have been able to bolster their own bargaining and negotiating positions as a result of endogenous factorsöprecisely because their responsibilities and authority have increased throughout the reforms. The states have benefited from a positive popular perception of devolution, which has increasingly held the central government to account. As Donahue (1997, page 13) asserts, "Contemporary opinion surveys ... show dwindling faith in the federal government and (at least in relative terms) rising state legitimacy ... [T] he fraction of respondents identifying the federal government as 'the level from which you feel you get least for your money' rose by 10 points (to 46\%) between 1989 and 1994 alone." This rise in legitimacy of the states has acted to curb the emphasis on responsibility so prominent in previous devolutionary efforts. As an illustration, President Clinton's reluctance to devolve responsibilities for medical health, although trumpeted as a moralistic decision in order to safeguard equity, was prompted by widespread resistance from the states, whose fears over defective funding procedures stemmed from their experience of welfare reform (Offner, 1999). As regional and state-level politics continues to become more important in the USA, such checks and balances will act to equalise the devolution of responsibilities and resources. In the future, greater devolution of resources to the states may become a political necessity for the centre.

\section{The impacts of the devolutionary trend}

At this point we are able to draw two conclusions. First, as evidenced in section 3 , the devolutionary trend is a common and general one. Second, however, this generality should not be mistaken for homogeneity. As we revealed in section 4 , there are different forms of devolution that arise from different legitimacy distributions. In this section we reassess the implications of the trend in light of its virtual universality and complexity.

From a strategic political perspective we should not be surprised to learn that awareness of the advantages of devolution tend to be more developed than awareness of its drawbacks. Whether devolution is driven mostly by national or subnational govern- 
ments, each potential driver has an inherent interest in defending its policies to the electorate and bolstering its legitimacy and popularity. The most common supporting arguments for devolutionary policies draw upon the efficiency advantages that lower level governance can engender (Donahue, 1997; Keating, 1999; Oates, 1972; Tanzi, 1996, pages $\left.297^{\wedge} 300\right)$. Given that the population in any country has a diverse preference structure, which varies across geographical space, this efficiency has three major sources, the themes of which recur time and again (Litvack et al, 1998, page 5; Oates, 1972). First, a smaller democratic and financial base should result in a managerial reform that will lead to a heightened degree of accountability, bolstered by the reduced administrative distance between the electorate and the politicians (Bennett, 1990; Hatry, 1994). Second, the lack of diluting influencesöexperienced by central government having responsibility for alternative, diverse regionsötends to allow local governments the flexibility to respond to the preferences of their 'customers' or electorates (Bennett, 1990). Third, the local nature of governance implies a greater chance of the election of local politicians with the specialist knowledge necessary to detect and react to the wishes of the electorate and defend its interests at higher levels (Putnam, 1993) as well as increasing the ability to implement policy innovations that would have been more difficult to pursue at the central or federal level (Bennett, 1990; Donahue, 1997). Devolutionists therefore acknowledge these three factors act both to ensure that local governments are more representative of and responsive to the interests of a given locality or region and to allow them to fulful this role. Thus, public policy in general is brought closer into line with the diverse preference sets of a nation, and welfare efficiency increases. Moreover, for those whose interests are not represented in their original location, there is in theory an increasing opportunity to choose and move between regional and local governmental systems as devolution progresses and as the diversity of public systems available to a nation as a whole increases. Arguments in favour of devolution are therefore underpinned by free-market assumptions, such as easy mobility, the politicoeconomic machinery of choice and democracy, and rational models of public sector behaviour under a democratic framework (see Tanzi, 1996, page 300).

There are areas, however, where developments associated with the global decentralising trend we have identified above cast doubt on the picture of greater efficiency, greater democracy, and greater welfare painted by devolutionists. As Prud'homme (1994, pages $\left.1.2^{\wedge} 1.3\right)$ outlines, the enthusiasm for devolution is driven not only by a commonly ill-considered faith in economic arguments but also by considerations of strategy on the part of ruling elites, the often 'fashionable' aura surrounding the concept of devolution, and the encouragement of international organisations, such as theWorld Bank, whose support for devolution is at best based upon a weak analytical basis' (Prud'homme, 1995). Indeed, on such a basis, over 12\% of all World Bank project activity in 1998 included a decentralisation component (Litvack et al, 1998, page 1). The need to expound the merits of caution with regard to devolution is therefore manifest. Consequently, in the following subsections, we explore some of the less encouraging developments associated with devolution by focusing on three aspectsöefficiency issues, equity issues, and administrative issues.

\subsection{Efficiency issues}

\subsubsection{Devolution and debt}

As discussed in earlier sections, devolutionary initiatives in our case-study countries have often included some separation of responsibilities from resources. It is rare to find simultaneous decentralisation of responsibility and resources, as the driving actor behind devolutionary efforts will invariably have incentives to separate these two factors one way or another (Rodden, 2002a, page 684; also, see figure 1). Under these circumstances it is common to discover a mismatch between responsibilities and financing, which, as Bennett (1997, page 331) underlines, have inevitably led to the development of debts either at the central or at the local level, to a steady erosion of the linkage of local decisions to their financial consequences, and to growing tension between central governments and subnational administrations. The cases of India, 
Brazil, and Spain illustrate various ways in which devolution can encourage debt formation.

In India, central government debt has been one of the major drivers behind devolutionary efforts. Between 1980/81 and 1993/94 the internal debt of the central government doubled, and total internal state debts rose from $4.6 \%$ to $7 \%$ of GDP (Buiter and Patel, 1997, page 36). It is easy, therefore, to envisage a situation where the pressure on central government finances at least contributed to a decentralisation of expenditure responsibilities. With a strong centre and calls for greater regional autonomy, the temptation to engineer favourable forms of devolution that will assist in limiting the central deficit may well become overwhelming.

In cases where the states have played a key role in the decentralisation effort, the decentralisation of resources can contribute towards large central deficits and developing regional debtsöthe former because of the de facto decentralisation of resources and the latter through the moral-hazard problem of central government effectively underwriting the expenditure of regions [for a general exposition of this commitment problem, see Rodden (2002a); for an examination of the Brazilian case, see Rodden (2002b)]. Perhaps the most apparent case of this type of development is found in Brazil. In Brazil, where decentralisation initiatives have been driven more by the states than by the centre, states were allowed to accumulate huge debts, often resulting from the development of short-term populist policies by Brazilian governors, aimed at securing their grip on power (Dillinger and Webb, 1999; Rodr|"guez-Pose and Arbix, 2001). The generation of regional debts was traditionally perceived as a low-risk strategy by local politicians, because, first, the burden of the debt would fall on future generations and not on current voters and, second, states expected to be bailed out in the medium term by the federal government. This, in combination with a weak centre, the political survival of which during much of the second half of the 1990s depended on the support of regional politicians, created conditions where several Brazilian states defaulted on their debts (Rodden, 2002a, page 670).

A devolutionary process driven by the so-called 'historical' regions in Spain has led to the establishment of a system where, although in most regions regional finances are still largely based on central government grants, autonomous regions hold the upper hand (Rodr|"guez-Pose, 1996). The consequence of this situation has been an erosion of national control over regional spending and a weak fiscal accountability, leading to a spiralling of regional debt across Spain (Castells, 2001; Montero, 2001).

\subsubsection{Inefficient competition for industry}

Another factor that threatens to proceed from efforts towards administrative devolution concerns the phenomenon of territorial competition. The proliferation and greater powers of subnational governments are shifting the focus of development policies away from achieving greater equality or national cohesion, towards securing greater economic efficiency at the local level (Cheshire and Gordon, 1998). Consequently, there has been an increasing tendency for subnational governments to engage in competition for the attraction of foreign direct investment (FDI) (Scott, 1998; Vernon, 1998). When subnational governments offer incentives for mobile industry to locate within their region, and the private sector firm chooses between the most attractive packages offered by the states, the impact upon national efficiency can be damaging. Cheshire and Gordon (1996) conceptualise this situation in terms of a zero-sum gameöone in which the aggregate payoff of the game for all the actors involved is independent of the final outcome of the game across the actors. Specifically, the total gain of the arrival of a firm in a given country will be the same, or very similar, no matter where within the country the firm chooses to locate. But there are costs involved in trying to affect the locational decision of the firm that stem from the sort of measures offered to the mobile firmsö such as tax grants, incentives and subsidies, or specific policy arrangements for foreign investorsöthat contribute to the spiralling of subnational debt (Rodr|"guez-Pose and Arbix, 2001). So, although the nation as a whole has nothing to gain as regions compete 
for investment it has much to lose as competition for mobile investment increases and regional advertising and marketing, government grants and loans, and interest and debt concessions increase. There are numerous examples of this sort of zero-sum competition for industry across Europe and the USA (Donahue, 1997; Mytelka, 2000; Phelps and Tewdwr-Jones, 2001) but it is perhaps in Brazil and China where the level of inefficiency associated with this sort of territorial competition is more apparent.

Of all the industries in Brazil, the automobile industry represents the clearest illustration of a general tendency. The Brazilian automobile industry expanded rapidly during the relatively stable period between 1995 and 1999 at the start of President Cardoso's term in office. During that time, car manufacturers invested over US \$12 billion in Brazil (Rodr|"guez-Pose and Arbix, 2001, page 134). Although this influx of FDI appears to be beneficial to the whole country, industrial mobility has created the conditions for fierce rivalry between Brazilian states hoping to attract investment and consequently it has paved the way for wasteful expenditure designed to influence companies' locational decisions. As has been pointed out elsewhere, 'Tax and bidding wars have become the norm in the motor industry" (Rodr|"guez-Pose and Arbix, 2001, page 145), with concessions routinely including the donation of land, the provision of infrastructure, state and local tax breaks, loans, and a series of financial cautions and guarantees.

In China, a similar pattern of territorial competition has become commonplace. Under the marketisation drive of the 1980s provinces, along with thousands of counties and townships, launched their 'opening up' programmes with the establishment of 'zones'. These were of differing varieties but each shared the common theme of offering significant concessions to attract industry, including, as a typical example, a 15\% flat rate on corporation tax, a two-year tax exemption on profits, and a further three-year $50 \%$ tax reduction. Ma (1996, page 15) documents the nature of these zones, which, by mid-1993, had swelled in number to around 1800 across China. Crucially, there were no official standards in the level of concessions that could be offered by the zones. The lack of an official standard of concessions has led to the development of intense competition, with concessions often extended well beyond the example above, towards extremes such as five tax-free years and a further five years of $50 \%$ tax payment. The impact on China as a whole of the development of these zones may well have been detrimental, for the reasons Cheshire and Gordon $(1996 ; 1998)$ provide. Ma (1996, page 15) points out that not only are concessions available to internationally footloose companies but also to indigenous companies in an attempt to attract them from one region to another. No discernible national economic gain from the resources expended on inducing these movements, which boil down to a simple spatial reallocation of industry within the nation, can be expected. Furthermore, McKenney (1993, pages $20^{\wedge} 21$ ) points out that in Beijing, one of the richer and more tax-effective areas in China, the ability of the subnational government to extract the taxes rightfully owed to them in their economic zones has been extremely poor. All in all, although much industry has been attracted to China through the use of economic zones, especially from Hong Kong, Taiwan, and Singapore, the efficiency cost through competitive concession making across provinces detracts markedly from the advantages.

\subsection{Equity issues}

One of the traditional roles of national government is the redistribution of resources in order to safeguard minimum levels of welfare throughout the country. Decentralisation of authority and resources undermines a central government's ability to achieve this, in two fundamental ways. First, devolution of decisionmaking authority progressively transfers the responsibility for devising ways in which redistribution will occur to subnational government. Second, this tier of government is multifarious, and it is often the case that larger or more prosperous regions are overrepresented at this level. Hence, following devolution, a smaller role for national transfers and a larger voice for the regions in deciding how transfers are allocated is likely to result in a less progressive system of fiscal redistribution than would be the case under a centralist 
system (Thompson, 1989) unless an explicit and transparent interterritorial fiscal transfer system is established. The political and economic muscle of stronger regions is likely to skew public expenditure in their favour, regardless of whether the greatest legitimacy is based in the centre or in the regions and of whether the financing system of regions is based on local tax revenue or on grants from the centre.Where the finance system is locally based, the devolution of fiscal powers will inevitably favour wealthier areas, and where the finance system is centrally based the greater political muscle of larger and richer regions may be reflected in a greater capacity to secure transfers from the centre and to impede the evolution of a more centralised regional system of transfers or regional policy, as Markusen (1994) demonstrated in the US case. In figure 3 we illustrate the regressiveness of regional budgets in three of our casestudy countries: Mexico, the USA, and Spain. The three cases represent three different forms of devolution and three different forms of regional financing, yet, in all cases, regions with the highest GDP per capita enjoy, as a general rule, a greater capacity for expenditure than do poorer regions. The positive regression lines in the graphs confirm this trend (figure 3).

\subsection{Institutional and political issues}

Three further issues concerning the understated downside of the devolutionary trend outlined in section 2 merit attention. First, and most obviously, devolution involves an increase in the number and a decrease in the size of administrative units, with accompanying costs. Second, more subtly, lobbying costs under a decentralised system are likely to exceed those under a central system. In much the same way that regions compete for mobile capital, subnational governmental units also compete for central

\section{FIGURE 3 HERE}

Figure 3. The regressiveness of regional budgets in 1999 in (a) Mexico, (b) the USA, and (c) Spain: expenditure per capital (average . 100) in relation to GDP per capita (average . 100).

The global trend towards devolution and its implications 347

financial assistance (see Milgrom and Roberts, 1992), and, as for competitive bidding between regions, the expense incurred during the process of competition for government financing is a deadweight loss to the nation as a whole. Moreover, we can expect these losses to become greater as subnational governments become more powerful and complex. The proliferation of intragovernmental conventions and reviews of fiscal relationsöfor example, in Brazil (1989), China (1994), and Mexico (1995)öunderscore the importance, complexity, and expense associated with public redistribution. Third, devolution of authority carries with it the threat of increased corruption (Rodden, 2002a, page 684). As Prud'homme (1994, pages $\left.2.17^{\wedge} 2.21\right)$ points out, although corruption is hard to measure, several reasons can be given for suspecting corruption rates to be higher at local levels. On the one hand, more opportunities for corruption probably exist, along with greater pressure from interest groups resulting from their proximity to local decisionmakers. On the other hand, fewer obstacles exist to prevent corruption. Local officials typically enjoy more discretion over funds than do those at the national level as well as more long-standing and personal relationships with stakeholders, creating the conditions for unethical relations that are promoted further by a relative lack of media scrutiny at lower governmental levels (Prud'homme, 1995). Furthermore, in Tanzi's (1996, page 301) view, contiguityöthe fact that officials and citizens live and work close to one another and have often known each other for some time and may even be relatedöserves to undermine the ethics of local governmental institutions.

\section{Conclusions}

The purpose of this paper has been to bring to attention the general trend in decentralisation and to outline the complexity of its forms and implications. To this end, some of the key issues surrounding the mechanisms of devolution were addressed and incorporated into an informal model at the start of the paper. In this model we identified three factors of decentralisation as composing the devolutionary trendö 
legitimacy, and the decentralisation of resources and authority. Some of the interest conflicts arising from the coexistence of these attributes of devolution were addressed in order to deepen our understanding of devolutionary mechanics. The relevance of this understanding became clear in section 3 , in which we outlined the depth and breadth of the global trend towards devolution. In those countries with centralised systems twenty or thirty years ago, decentralisation has been widespread, and in those countries with initially more vertically dispersed government systems further decentralisation from their respective starting points has become the norm. This global tendency towards the devolution of authority and resources elevates the importance of the need to understand this phenomenon. To this end, in section 4 the theoretical arguments given in section 2 were then applied to our group of case-study countries, exposing the diversity of devolutionary efforts across the globe.

In section 5, given the understated heterogeneity of devolutionary processes, the parallel heterogeneity of devolutionary implications was addressed. The expectation that devolution leads to greater efficiency, as the devolutionists and many policymakers appear to hold, can be called into question on the grounds that the process tends to engender both debt and territorial competition which are harmful to national efficiency. The gains from devolution through the matching of public services to a heterogeneous population preference structure is a static argument that may overlook dynamic alterations in the behaviour of the actors involved. From either perspective, the incentive structure facing the national and subnational governments alter and present the potential for opportunistic interaction that is damaging for the economy as a whole. Although the matching argument remains strong it should be weighted against the expected losses resulting from these factors before any devolutionary processes are undertaken.

In terms of equity, evidence was present to support the case that decentralisation of resources is often regressive from a territorial point of view. The combination of dwindling central government outlays in relative terms with the greater bargaining power of the richer and/or larger subnational authorities frequently leaves weaker and poorer regions in a worse financial state than under a centralised system. In section 5 we provided a brief discussion of the administrative, lobbying, and corruption costs that devolution is also likely to entail.

In summary, it is imperative for policymakers to recognise varying forms of decentralisation and to be aware of the vested interests of national and subnational governments across these alternative devolutionary forms. It is also imperative that commentators, policymakers, and analysts remain aware of the context of debates and opinions surrounding devolution. It is no coincidence that devolution tends to be supported by national electorates, because powerful and influential actors seek to muster the support of the electorate to facilitate their own initiatives. At the same time, however, this situation might well be damaging if enthusiasm for devolution is not tempered with, first, an awareness of the context of any debates that occur and, second, an awareness of not just the benefits but also the understated drawbacks that devolution can engender. As Tanzi (1996, page 314) has emphasised, successful devolution is highly dependent upon a long list of preexistent circumstances, the generation and, equally, consideration of which are by no means assured. The prescription of this paper is therefore cautionary with respect to both the interpretation and the promotion of devolutionary efforts.

Acknowledgements. The authors would like to thank Robert Bennett, Gilles Duranton,Murray Low, and two anonymous referees for their comments to earlier drafts of this paper. Andre"s Rodr|"guezPose gratefully acknowledges the financial support of the Royal Society ${ }^{\wedge}$ Wolfson Research Merit Award and Philip Leverhulme Prize during this research.

\section{References}

Agnew J, 2000, "From the political economy of regions to regional political economy" Progress in Human Geography $24101^{\wedge} 110$ 
Allmendinger P, Tewdwr-Jones M, 2000, “'Spatial dimensions and institutional uncertainties of planning and the 'new regionalism' " Environment and Planning C: Government and Policy 18 $711^{\wedge} 726$

Aspinall E, Berger M T, 2001, “'The break-up of Indonesia? Nationalisms after decolonisation and the limits of the nation-state in post-cold war Southeast Asia" Third World Quarterly 22 $1003^{\wedge} 1024$

Bagchi A, Bajaj J L, Byrd W (Eds), 1992 State Finances in India (Vikas, New Delhi)

Bahl R, 1999 Fiscal Policy in China (1990 Institute, San Francisco, CA)

Bennett,RJ,1990Decentralization, Local Governments andMarkets:Towards a Post-welfareAgenda (Clarendon Press, Oxford)

Bennett R J, 1997, “Administrative systems and economic spaces" Regional Studies $31323^{\wedge} 336$

BuiterW H, Patel U R, 1997, " Solvency and fiscal correction in India", in Public Finance: Policy

Issues for India Ed. S Mundle (Oxford University Press, Oxford) pp $30^{\wedge} 75$

CastellsA, 2001, "The role of intergovernmental finance in achieving diversity and cohesion: the case of Spain" Environment and Planning C: Government and Policy $19189 \wedge 206$

Castells M, 1996 The Rise of the Network Society (Blackwell, Cambridge, MA)

Cheshire P C,Gordon I,1996, 'Territorial competition and the predictability of collective (in)action" International Journal of Urban and Regional Research $20383^{\wedge} 400$

Cheshire P C, Gordon I, 1998, “'Territorial competition: some lessons for policy"Annals of Regional Science $323210 ̈ 346$

CoutinhoM,1996, "The Brazilian fiscal system in the 1990s: equity and efficiency under inflationary conditions", RP 41, Institute of Latin American Studies, University of London, London

The global trend towards devolution and its implications 349

Da-dao L, Sit V, 2001, "China's regional development policies: a review", in China's Regional

Disparities: Issues and Policies Eds V Sit, L Da-dao (Nova Science Publishers, Hauppauge,

NY) pp $19 \wedge 37$

Diamanti I, 1993 La Lega: Geografia, Storia e Sociologia di un Nuovo Soggetto Politico

(Donzelli, Rome)

Dicken P,1998 Global Shift:Transforming theWorld Economy 3rd edition (Guilford Press,NewYork)

DillingerW,Webb S B, 1999, "Fiscal management in federal democracies: Argentina and Brazil",

Policy ResearchWorking Paper 2121, World Bank,Washington, DC

Donahue J D, 1997 Disunited States (HarperCollins, New York)

Ebel R, Yilmaz S, 2002, "'On the measurement and impact of fiscal decentralization", http://econ.worldbank.org/files/13170_wps2809.pdf

Gray J, 1998 False Dawn: The Delusions of Global Capitalism (Granta Books, London)

Guigale M M,Webb S B, 2000 Achievements and Challenges of Fiscal Decentralisation: Lessons from Mexico (World Bank, Washington, DC)

Hagopian F, 1996 Traditional Politics and Regime Change in Brazil (Cambridge University Press, Cambridge)

Hatry H, 1994, “Accountability for service quality, performance measurement and closeness to customs", in Local Government and Market Decentralisation Ed.R J Bennett (United Nations University Press, Tokyo) pp $163^{\wedge} 181$

IMF, various years Government Finance Statistics (InternationalMonetary Fund,Washington,DC) ICSO, 1999 Statistical Abstract of India (Indian Central Statistical Organisation, Delhi)

JonesM, 2001, 'The rise of the regional state in economic governance: 'partnerships for prosperity' or new scales of state power?" Environment and Planning A $331185^{\wedge} 1211$

Kraemer M, 1997, "Intergovernmental transfers and political representation: empirical evidence from Argentina, Brazil and Mexico",WP 345, Inter-American Development Bank, 1300 New York Avenue NW,Washington, DC 20577

Keating M, 1998 The New Regionalism inWestern Europe (Edward Elgar, Northampton, MA)

Keating M, 1999, "Asymmetrical government: multinational states in an integrating Europe"

Publius Journal of Federalism $1971 \wedge 87$

Lee P K, 2000, “Into the trap of strengthening state capacity: China's tax assignment reform"

The China Quarterly $1641008^{\wedge} 1024$

Litvack J, Ahmad J, Bird R, 1998 Sector Studies Series 21491: Rethinking Decentralisation in Developing Countries (World Bank,Washington, DC)

Ma J, 1996 Intergovernmental Relations and Economic Management in China (St Martin's Press, New York)

McKenney K I, 1993, “An assessment of China's special economic zones", The Industrial College of the Armed Forces, National Defence University,Washington, DC

Markusen A, 1994, "American federalism and regional policy" International Regional Science

Review $163^{\wedge} 15$

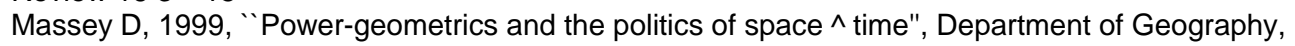
University of Heidelberg, Heidelberg

Milgrom P, Roberts J, 1992 Economics, Organisation and Management (Prentice-Hall, Englewood Cliffs, NJ) 
Montero A P, 2000, “'Devolving democracy? Political decentralisation and the New Brazilian Federalism", in Democratic Brazil: Actors, Institutions and Processes Eds P R Kingstone, T J Power (University of Pittsburgh Press, Pittsburgh, PA)

Montero A P, 2001, "Decentralizing democracy: Spain and Brazil in comparative perspective" Comparative Politics $33149 \wedge 172$

Morgan K, 2002, “'The English question: regional perspectives on a fractured nation" Regional Studies $36797 \wedge 810$

Mytelka L K, 2000, “'Location tournaments for FDI: inward investment into Europe in a global world", in The Globalization of Multinational Enterprise Activity and Economic Development

EdsN Hood, S Young (Macmillan, London) pp $278^{\wedge} 302$

OatesW E, 1972 Fiscal Federalism (Harcourt Brace Jovanovich, New York)

Offner P, 1999 Medicaid and the States: A Century Foundation Report (Century Foundation

Press, New York)

Pe"rez D|"az V, 1990, "Governability and the scale of governance: mesogovernments in Spain", WP 1990/6, Instituto Juan March de Estudios e Investigaciones, Madrid

Phelps NA,Tewdwr-JonesM, 2001, “Globalisation, regions and the state: Exploring the limitations of economic modernisation through inward investment" Urban Studies $38125{ }^{\wedge} 1272$

350 A Rodr|"guez-Pose, N Gill

Ping X, 2000, "The evolution of Chinese fiscal decentralisation and the impacts of tax reform in 1994" Hitotsubashi Journal of Economics $41179^{\wedge} 191$

Powers E T, 1999, "Block granting welfare: fiscal impact on the states", OP23, Urban Institute, Washington, DC

Prud'homme R, 1994, “On the dangers of decentralization",WP-1252,World Bank,Washington, DC Prud'homme R, 1995, "The dangers of decentralization"World Bank Research Observer 10201 ^ 220 Putnam, R J, 1993Making DemocracyWork: CivicTraditions inModern Italy (Princeton University Press, Princeton, NJ)

RBI, 2000, "State finances: a study of budgets of $1999^{\wedge} 2000^{\prime}$, Reserve Bank of India, Mumbai Rodden J, 2002a, "'The dilemma of fiscal federalism: grants and fiscal performance around the world"American Journal of Political Science $46670 \wedge 687$

Rodden J, 2002b, "Bailouts and perverse incentives in the Brazilian states" http:// www1.worldbank.org/publicsector/decentralization/cd/Brazil.pdf

Rodr|"guez V E, 1998, "'Recasting federalism in Mexico" Publius Journal of Federalism $28232^{\wedge} 254$

Rodr|"guez-Pose A, 1996, "Growth and institutional change: the influence of the Spanish regionalisation process on economic performance" Environment and Planning C: Government and Policy $1471^{\wedge} 87$

Rodr|"guez-Pose A, 1998 Dynamics of Regional Growth in Europe: Social and Political Factors (Clarendon Press, Oxford)

Rodr|"guez-Pose A, 2002 The European Union: Economy, Society, and Polity (Oxford University

Press, Oxford)

Rodr|"guez-Pose A, Arbix G, 2001, "'Strategies of waste: bidding wars in the Brazilian automobile sector" International Journal of Urban and Regional Research $25134^{\wedge} 154$

Schram S F, Soss J, 1998, "Making something out of nothing: welfare reform and a new race to the bottom" Publius Journal of Federalism $2867^{\wedge} 88$

Scott A J, 1998 Regions and theWorld Economy:The Coming Shape of Global Production, Competition, and Political Order (Oxford University Press, Oxford)

Shah A, 1991, "'The new fiscal federalism in Brazil", DP 124,World Bank,Washington, DC

Sharma S D, 1999 Development and Democracy in India (Lynne Rienner, Boulder, CO)

Souza C, 1997 Constitutional Engineering in Brazil: The Politics of Federalism and Decentralization (Macmillan, London)

StorperM, 1997 The RegionalWorld:Territorial Development in a Global Economy (Guilford Press, New York)

Sury M M, 1998 Fiscal Federalism in India (Indian Tax Institute, Delhi)

Tanzi V, 1996, " 'Fiscal federalism and decentralization: a review of some efficiency and macroeconomic aspects", in Annual World Bank Conference on Development Economics (World Bank,Washington, DC) pp $295^{\wedge} 316$

Thompson C, 1989, "Federal expenditure-to-revenue ratios in the United States of America, $1971^{\wedge}$ 85: an exploration of spatial equity under the 'new federalism"' Environment and Planning C: Government and Policy $7445^{\wedge} 470$

Tomaney J, 2000, "End of the empire state? New labour and devolution in the United Kingdom" International Journal of Urban and Regional Research $24675^{\wedge} 688$

Tomaney J,Ward N, 2000, “'England and the 'new regionalism' " Regional Studies $34471 \wedge 478$

Vernon R, 1998 In the Hurricane's Eye: The Troubled Prospects of Multinational Enterprises (Harvard University Press, Cambridge, MA)

Ward P M, Rodr|"guez V E, 1999, "New federalism and state government in Mexico: bringing the states back in", AS ^Mexican Policy Report 9, University of Texas at Austin, Austin, TX

Yi L, Chusheng L, 2001, "The tax division scheme: central ^ local financial relations in the 1990s", 
in China's Regional Disparities: Issues and Policies Eds V Sit, L Da-dao (Nova Science

Publishers, Hauppauge, NY) pp $85^{\wedge} 104$

The global trend towards devolution and its implications 351

B 2003 a Pion publication printed in Great Britain 